DERLEME / REVIEW

Balıkesir Sağlık Bilimleri Dergisi / BAUN Sağ Bil Derg

Balıkesir Health Sciences Journal / BAUN Health Sci J

ISSN: 2146-9601- e ISSN: 2147-2238

doi: https://doi.org/10.53424/balikesirsbd.804250

\title{
Hemşirelik Sınıflama Sistemlerine Göre Ağız ve Diş Sağlığı Hizmetlerinde Hemşirelik Sürreci
}

\author{
Reva BALCI AKPINAR ${ }^{1}$, Elif KANT 2 \\ ${ }^{1}$ Atatürk Üniversitesi, Hemşirelik Fakültesi, Hemşirelik Esasları Anabilim Dalı \\ ${ }^{2}$ Atatürk Üniversitesi, Sağlık Hizmetleri Meslek Yüksek Okulu
}

Geliş Tarihi / Received: 02.10.2020, Kabul Tarihi / Accepted: 04.11.2020

*Bu makale 14-16 Kasım 2019 tarihleri arasında 1. Uluslararası 4. Geleneksel Sağlık Çalışanları Meslek Günleri Sempozyumunda Sözel Bildiri olarak sunulmuştur.

\section{ÖZ}

Ağız ve diş sağlığı hizmetleri, toplum sağlığının korunup geliştirilmesi hedefinin gerçekleştirilmesinde, bireylerin ağız ve diş sağlığını korumaya ve tedavi etmeye yönelik hizmetlerdir. A $\breve{g} ı$ bakımı, ağız ve diş sağlığının korunmasına yönelik sağlık eğitiminden, iyi bir oral değerlendirme ve tedaviye kadar önemli hemşirelik bakım aktivitelerinden biri iken, hemşirelerin bu alandaki rolleri büyük ölçüde ihmal edilmiştir. Hemşireler; gerek ağız ve diş sağlığının korunmasında, gerekse tedavi sürecinde hemşirelik süreci ile bireyi değerlendirip, hemşirelik tanısı doğrultusunda bakım planını oluşturarak uygun girişimleri yapabilir. Bu makalenin amacı; Hemşirelik Sınıflama Sistemlerine uygun olarak ağız ve diş sağlığı hizmetlerinin sunumunda sık karşılaşılan hemşirelik tanıları, hemşirelik girişimleri ve hemşirelik sonuçları hakkında yazılı kaynak oluşturmaktır. Bu makale ağız diş sağlığı biriminde çalışan hemşirelere, hasta bakım sürecinde sistematik ve bütüncül bir yaklaşım sergilemelerine rehber olacaktır.

Anahtar Kelimeler: Ağız Diş Sağlığı, Hemşirelik Süreci, Hemşirelik Tanıları, Hemşirelik Girişimleri, Hemşirelik Sonuçları, Hemşirelik Sınıflama Sistemleri.

\section{Nursing Process in Oral and Dental Health Services According to Nursing Classification Systems}

\begin{abstract}
Oral and dental health services are the services aimed at protecting and treating the oral and dental health of individuals in the realization of the aim of protecting and improving public health. Oral care is one of the important nursing care activities, from health education to oral and dental health to good oral evaluation and treatment, while the role of nurses in this area has been largely neglected. Nurses: evaluate the individual through the nursing process both in the protection of oral and dental health and in the treatment process and make appropriate interventions by creating a care plan in line with the diagnosis of nursing. The purpose of this article to provide written resources about nursing diagnoses, nursing interventions and nursing outcomes frequently encountered in the provision of oral and dental health services in accordance with Nursing Classification Systems. This article will guide the nurses working in oral and dental health unit to take a systematic and holistic approach in patient care process.

Keywords: Oral Dental Health, Nursing Process, Nursing Diagnosis, Nursing Interventions, Nursing Outcomes, Nursing Classification Systems.
\end{abstract}

Sorumlu Yazar / Corresponding Author: Reva BALCI AKPINAR, Atatürk Üniversitesi, Hemşirelik Fakültesi, Hemşirelik Esasları Anabilim Dalı, Erzurum, Türkiye.

E-mail: reva@atauni.edu.tr

Bu makaleye atıf yapmak için / Cite this article: Balcı Akpınar, R, Kant, E. (2021). Hemşirelik Sınıflama Sistemlerine Göre Ağız ve Diş̧ Sağlı̆̆ Hizmetlerinde Hemşirelik Süreci. Balıkesir Sağllk Bilimleri Dergisi, 10(2),214-226. https://doi.org/10.53424/balikesirsbd.804250

CCopyright 2021 by the Balıkesir Sağlık Bilimleri Dergisi.

BAUN Să̆ Bil Derg 2021 OPEN ACCESS https://dergipark.org.tr/tr/pub/balikesirsbd

This work is licensed under a Creative Commons Attribution-NonCommercial 4.0 International License. 


\section{GíRIŞ}

Genel sağlığın ayrılmaz bir parçası olan ağız ve diş sağlığı, yalnızca dişlerle ilgili değil, diş etleri, bunları destekleyen dokular, ağız mukozal yapılar, dil ve dudakları da kapsayan bir kavramdır. Geniş bir hedef kitleyi kapsayan ağız ve diş sağlı̆̆ hizmetleri ülkemizde büyük oranda tedavi edici hizmetler olarak sunulmaktadır (Akar, 2014). Bu hizmetler genel olarak kamuda, üniversitelerde ve özel merkezlerde verilmektedir (Tatar ve ark., 2011). Ağız sağlığ1 insanları fiziksel, ruhsal ve sosyal yönden etkiler (Çolak, Dülgergil \& Serdaroğlu, 2010). Ağız fonksiyonlarının bozulması ve sağlıksız dişler, ağrı ve enfeksiyon başta olmak üzere birçok yakınmaya yol açabilmektedir (Kozier, Berman, Snyder \& Erb, 2008; Potter \& Perry, 2009; Taylor, Lillis, LeMone \& Lynn, 2008). Bireyin yemesini, içmesini, konuşmasını, sosyal hayatını sürdürebilmesini, olumlu beden algısı oluşturmasını, yaşam kalitesini ve genel sağlık durumunu yakından etkileyen ağız ve diş sağlığı, sağlıklı olmanın da önemli göstergelerindendir (Naito ve ark., 2006; Slade, 2002). Ağız ve diş sağlığının geliştirilmesinde diş hekimleri önemli ve primer roller üstlenmişlerdir. Ancak ağız ve diş sağlı̆̆ hizmetlerinin doğası, geniş bir hedef kitleye sunulan başta koruyucu olmak üzere tedavi edici sağlık hizmetlerinin iyi yönetilmesini gerektirmektedir. Bu hizmetlerin başarısı ancak rolleri net olarak tanımlanmış ekip çalışması ile mümkündür (Kılınç \& Günay 2010). Hemşireler; bireyin, ailenin ve toplumun gereksinim duyduğu koruyucu ve tedavi edici sağlık hizmetlerinde görev alan profesyonellerdir. Ağız bakımı, ağız ve diş sağlığının korunmasına yönelik sağlık eğitiminden, iyi bir oral değerlendirme ve tedaviye kadar önemli hemşirelik bakım aktivitelerinden biri iken (Karamanoğlu \& Yavuz, 2015) hemşirelerin bu alandaki rolleri büyük ölçüde ihmal edilmiştir. Ağız ve diş sağlığı merkezinde çalışan hemşirelere; hastanın tedavi sürecinde diş hekimine yardım sağlaması, gerekli malzemeleri hazırlaması, kullanılmış aletleri temizlemesi ve sterilize etmesi, hastanın ağı sağlığı ile ilgili bilgilerini kaydetmesi, radyografileri işlemesi ve stok kontrolü gibi görevler verilmiştir. Oysaki profesyonel hemşirelik, üstlendiği çağdaş rolleri ile bireyin tüm bakım ortamlarında, en iyi hemşirelik bakımını almasını sağlayacak şekilde, hemşirelik bakımını organize etme ve sağlamada sistematik yaklaşımı benimsemektedir. Bu yaklaşım, hemşirelik sürecidir. Hemşirelik süreci, sağlıklı/hasta bireyin sağlık bakım gereksinimlerinin tanımlanması ve bireye özgü bakımın verilmesinde kullanılan sistematik bir yöntemdir (Sabuncu, 2008). Hemşirelik uygulamalarına bilimsel bir kimlik kazandıran hemşirelik süreci bir plan doğrultusunda bakım verilmesini ve zamanın daha etkin kullanmasını sağlar. Ekip üyeleri arasında iletişimi geliştirir, hemşirelik eğitimi ve araştırmaları için yazılı kaynakları ve kanıtları oluşturarak hemşirelik hizmetlerini görünür kılar (Birol, 2011). Ancak geleneksel hemşirelik süreci kanıta dayalı uygulama ve hemşirelik sınıflandırma sistemlerinden uzaktır. Modern hemşirelik sürecinde ise hemşirelik sınıflandırma sistemlerinde tanımlanmış, kanıta dayalı, geçerli ve standardize kavramlar kullanılır (Rabelo Silva ve ark., 2017). Hemşirelik sınıflandırma sistemleri hemşirelerin ele aldığı hasta sorunlarını, bu sorunların çözümüne yönelik uyguladıkları kanıta dayalı hemşirelik girişimlerini ve bu girişimlerin hasta sonuçları üzerindeki etkisini adlandırmayı ve sinıflandırmayı sağlar (Birol, 2011). Dünya genelinde hemşireler tarafından; 12 farklı "hemşirelik sınıflama sistemi" kullanılmaktadır. Bu siniflama sistemlerinden Kuzey Amerika Hemşirelik Tanıları Birliği-Uluslarası (The North American Nursing Diagnosis AssociationInternational NANDA-I) Sinıflama Sistemi, Hemşirelik Sonuçları Sinıflaması (Nursing Outcomes Classification- NOC), Hemşirelik Girişimleri Sinıflaması (Nursing Intervention Classification-NIC) en iyi bilinen hemşirelik sınıflama sistemleridir (Herdman \& Kamitsuru, 2018; Park, 2014; Tastan ve ark., 2014). Hemşirelik tanıları, hemşirenin bağımsız olarak uygun hemşirelik yaklaşımları ile önlemek, hafifletmek ya da çözümlemek için yasal olarak ele almaya yetkili olduğu birey/aile/grupların var olan ya da olası sağlık sorunlarıdır. Hemşirelik tanıları, bireyin sağlık sorununa yönelik ne yapılması gerektiği konusunda hemşirelik girişimlerinin seçimine rehberlik eder ve ulaşılacak sonuçlar için bir temel oluşturur. Her hemşirelik tanısı, tanı ismi, tanım, tanımlayıcı faktör, risk faktörü ve etyolojik faktör birleşenlerinden oluşur (Birol, 2011). NANDA-I 2018-2020 listesinde toplam 244 hemşirelik tanısı yer almaktadır (Herdman \& Kamitsuru, 2018).Hemşirelik Girişimleri Sınıflaması (NIC), her alanda ve her ortamda hemşirelerin yerine getirdiği işlemleri/girişimleri tanımlamak üzere standardize edilmiş, kapsamlı bir sınıflama sistemidir. Hemşirelik girişimi, sağlıklı/hasta bireyde istendik bakım sonuçlarını elde etmek için hemşirenin klinik kararına, bilgisine ve becerisine dayalı hemşirelik aktivitelerinden oluşmuş uygulamalardır. Hemşirelik girişimlerinin herbirinin adı, dört basamaklı sayıdan oluşan kodu, tanımı ve girişime ait aktiviteleri bulunmaktadır. Bir girişim, hemşirelik tanısının özellikleri, hasta sonuçları (NOC), girişimin araştırma temeli, girişimi yapmanın uygunluğu, hasta için kabul edilebilirliği ve hemşirenin girişimi uygulayabilme kapasitesi gözönünde bulundurularak seçilir. 2018 yılında yayımlanan 7. Baskıda NIC'te 565 hemşirelik girişimi yer almıştır (Ackley, 2019; Butcher ve ark., 2018). Bireyin mevcut sorununun ve hemşirelik girişimlerinin etkinliğinin değerlendirilmesinde ise Hemşirelik Sonuçları Sınıflaması (Nursing Outcomes Classification- NOC) sistemi kullanılmaktadır. Her bir sonucun, sınıflama içinde adı, tanımı, kod numarası ve göstergeleri bulunmaktadır (Ackley, 2019; CarpenitoMoyet, 2012; Butcher ve ark., 2018; Törnvall \& Jansson 2017; Nanda Nursing Diagnosis List, 2020; Royal College of Nursing-RCN, 2011). Göstergelerin puanlanması ile hemşirelik girişimlerinin sonuçları hakkında ölçülebilir nitel ve nicel veri elde edilmektedir. NOC sonuçları, sadece fonksiyonel ve fizyolojik durum ile sınırlı olmayıp aynı zamanda psikososyal, bilgi ve 
davranışsal durumun ölçümlerini de içermektedir. Her bir NOC sonucu, farklı sayıda göstergeye sahiptir ve göstergeler en olumsuzdan (negatiften) en olumluya doğru beşli likert ifadelerden oluşmaktadır. Göstergelerin hepsinde en az istenen durum ' 1 ', en çok istenen durum ' 5 ' sayıları ile belirtilmiştir. Hemşire bireyin hemşirelik tanısını belirledikten sonra, tanı ile ilgili durumu/ciddiyeti belirlemek için uygun NOC göstergesi seçimi yapmalıdır. NOC göstergesi seçimi yapılırken, belirlenen hemşirelik tanısının tipi, hemşirelik tanısına ilişkin tanımlayıcı özellikler, etiyolojik veya risk faktörleri, sonuca ulaşmayı etkileyebilecek hasta özellikleri, hastanın tercihleri, hemşirelik girişimine tepki verebilme olasılığı göz önünde bulundurulmalıdır. 2018 yılında yayımlanan 6 . Baskıda NOC'ta 540 sonuç yer almıştır (Moorhead ve ark.,2018). Hemşirelik tanılarının, hemşirelik sonuçlarının ve hemşirelik girişimlerinin kodları, hemşirelik bakımına ilişkin verilerin bilgisayar ortamına aktarılmasında kullanılmaktadır. NANDA-I tarafindan belirlenmiş hemşirelik tanılarına yönelik, NIC'te yer alan girişimlerin hemşirelik sürecinde kullanılması hemşirenin hastasına bütüncül bir bakış acısıyla bakım vermesini kolaylaştırır, hemşirelerin klinik karar verme ve eleştirel düşünme becerilerini destekleyerek hemşirelik bakım kalitesini artırır, hemşirelik araştırmalarına uluslararası düzeyde veri tabanı sağlar ve ortak bir dil oluşturur (Johnson ve ark., 2012; Törnvall \& Jansson 2017). Hemşirelik sonuçlarının nitel ve nicel olarak ortaya konulması bakımın değerlendirilmesini sağlamakla birlikte, hemşirenin çalışma ortamındaki varlığını görünür kılar (CarpenitoMoyet, 2012; Moorhead ve ark., 2018; Wilkinson \&
Barcus 2018; Ackley, 2019; Butcher ve ark., 2018; Nanda Nursing Diagnosis List, 2020).

Geleneksel derleme olarak hazırlanan bu makalede araştırmacıların gözlem ve deneyimlerinden yola çıkılarak belirlenen ve NANDA 2018-2020 hemşirelik tanıları listesinde yer alan ağız ve diş sağlığı sorunu olan hastalar için muhtemel hemşirelik tanıları, hemşirelik tanılarının etiyolojik faktörleri ve tanımlayıcı özellikleri (PES formatında), hasta durumunun değerlendirilmesinde yararlanılan NOC sonuçları ve göstergeleri, hemşirelik girişimleri ve bu girişimlere uygun hemşirelik aktiviteleri ilgili literatür incelenerek ele alınmıştır (Herdman \& Kamitsuru, 2018; Moorhead ve ark., 2018; Wilkinson \& Barcus 2018; Ackley, 2019; Butcher ve ark., 2018; Carpenito-Moyet, 2012; Nanda Nursing Diagnosis List, 2020), (Tablo1). Tabloda her hemşirelik tanısı için uygun olabilecek en az bir hemşirelik sonucuna, bu sonuçlardan birine ilişkin göstergelere (bilgi eksikliği tanısı için iki NOC sonucuna ait göstergeler verilmiştir), en az bir hemşirelik girişimine ve bu hemşirelik girişimlerinden birinin aktivitelerine yer verilmiştir. Aktivitelerin ve göstergelerin kodları tablo görselliğini bozmaması için yazılmamıştır. Hemşireler tabloda yer almayan ancak hastaları için uygun olan diğer hemşirelik tanılarını, hemşirelik sonuçlarını ve hemşirelik girişimlerini son yayınlanan listeden seçerek bakım alanlarında kullanabilirler.

$\mathrm{Bu}$ makalenin amacı; ağız ve diş sağ lı̆̆ sunumunda sık karşılaşılan hemşirelik tanıları, hemşirelik sonuçları ve hemşirelik girişimleri hakkında yazılı kaynak oluşturmaktır.

Tablo 1. Ağız ve diş sağlığı sorunu olan hastaların hemşirelik bakımında ele alınması gereken hemşirelik tanıları (pes formatında), hemşirelik sonuçları ve hemşirelik girişimleri.

\begin{tabular}{|c|c|c|c|c|}
\hline $\begin{array}{l}\text { Hemşirelik } \\
\text { Tanısı }\end{array}$ & $\begin{array}{l}\text { Etiyolojik } \\
\text { faktörler }\end{array}$ & $\begin{array}{l}\text { Tanımlayıcı } \\
\text { özellikler }\end{array}$ & $\begin{array}{l}\text { NOC } \\
\text { sonuçları }\end{array}$ & NIC girişimleri \\
\hline $\begin{array}{l}\text { Akut ağrı } \\
\begin{array}{l}\text { Altı aydan kısa } \\
\text { bir süre, bir } \\
\text { rahatsılık } \\
\text { duygusu ya da } \\
\text { şiddetli } \\
\text { rahatsızlığı } \\
\text { olduğunu } \\
\text { bildiren ve } \\
\text { bunu yaşayan } \\
\text { bireydeki } \\
\text { durumdur. }\end{array}\end{array}$ & $\begin{array}{ll}\text { - } & \text { Çene } \\
\text { cerrahisi } \\
\text { - } \text { Ağız ve diş } \\
\text { enfeksiyonu } \\
\text { - } \text { Diş } \\
\text { çürükleri }\end{array}$ & $\begin{array}{l}\text { - Çeneyi } \\
\text { ovma ya da } \\
\text { tutma } \\
\text { - Sizlanma } \\
\text { - Ağrisının } \\
\text { olduğunu } \\
\text { ifade etme }\end{array}$ & $\begin{array}{l}\text { 2102- Ağrı } \\
\text { düzeyi } \\
\text { 0004-Uyku } \\
\\
\text { A ğrı Düzeyi } \\
\text { Içcin Bazı } \\
\text { Göstergeler } \\
\text { (1-5 arası } \\
\text { puanlanır) } \\
\text { - Ağrı } \\
\text { bildirimi } \\
\text { - Ağrı süresi } \\
\text { - Ajitasyon } \\
\text { - Bölgeyi } \\
\text { ovalama }\end{array}$ & $\begin{array}{l}\text { 1400-Ağrı yönetimi } \\
\text { 2210-Analjezik uygulaması } \\
\text { Ağrı Yönetimi İçin Hemşirelik Aktiviteleri } \\
\text { - Ağrının özelliği, başlangıcı/süresi, sıklığı, niteliği, yoğunluğu, } \\
\text { şiddeti, ağrıyı arttıran ve azaltan durumları içeren kapsamlı } \\
\text { değerlendirme yapılır. } \\
\text { - Etkili iletişim kuramayan bireylerde sözel olmayan rahatsızlık } \\
\text { belirtileri gözlemlenir. } \\
\text { - Hastanın ağrı hakkındaki bilgi ve inançları incelenir. } \\
\text { - Ağrıya tepkide kültürel etkiler göz önünde bulundurulur. } \\
\text { - Ağrı deneyiminin yaşam kalitesi üzerine etkileri ( uyku, iştah, } \\
\text { aktivite, bilişsel durum, ruh hali, ilişkileri, ruh hali, iş } \\
\text { performansı, rol sorumlulukları ) tanımlanır. } \\
\text { - Ağrının nedeni, ne kadar süreceği ve işlemden dolayı beklenen } \\
\text { rahatsızlık miktarı gibi ağrı hakkında bilgi sağlanır. } \\
\text { - Hastanın rahatsızlığa tepkilerini etkileyebilecek çevresel } \\
\text { faktörler kontrol edilir. } \\
\text { - Ağrının şiddeti artmadan önce ağrı kontrol yöntemleri } \\
\text { kullanılır. } \\
\text { - Ağrılı işlem öncesi analjezi ve / veya non farmakolojik strateji } \\
\text { sağlanır. } \\
\text { - Ağrıyı gidermede önerilen analjezikleri kullanması için } \\
\text { bilgilendirilir. } \\
\text { - Uygun sıklıkta ağrı değerlendirmesi yapılır. }\end{array}$ \\
\hline
\end{tabular}


Tablo 1. (Devam). Ağız ve diş sağlığı sorunu olan hastaların hemşirelik bakımında ele alınması gereken hemşirelik tanıları (pes formatında), hemşirelik sonuçları ve hemşirelik girişimleri.

\begin{tabular}{|c|c|c|c|c|}
\hline $\begin{array}{l}\text { Hemşirelik } \\
\text { Tanısı }\end{array}$ & $\begin{array}{l}\text { Etiyolojik } \\
\text { faktörler }\end{array}$ & $\begin{array}{l}\text { Tanımlayıcı } \\
\text { özellikler }\end{array}$ & NOC sonuçları & NIC girişimleri \\
\hline $\begin{array}{l}\text { Alerjik yanıt riski } \\
\text { Vücudun bağışılılık } \\
\text { sisteminin yabancı bir } \\
\text { maddeye (antijen) yanıt } \\
\text { verme riski bulunma } \\
\text { durumudur. }\end{array}$ & $\begin{array}{l}\text { Risk Faktörleri } \\
\text { - Oral hijyen } \\
\text { ürünleri (Ağız } \\
\text { gargaraları, diş } \\
\text { ipi ve diş } \\
\text { macunları) } \\
\text { - Dental restoratif } \\
\text { materyaller } \\
\text { (Altın, akril, } \\
\text { ortodontik teller, } \\
\text { ölçü maddeleri } \\
\text { ve amalgam) } \\
\text { - Lateks içeren } \\
\text { malzemeler }\end{array}$ & - & $\begin{array}{l}\text { 0706-Alerjik tepki } \\
\text { 0802-Vital bulgular } \\
\text { 1902-Risk kontrolü } \\
\text { Alerjik tepki İçin } \\
\text { Bazı Göstergeler } \\
\\
\quad \text { (1-5 arası } \\
\text { puanlanır }) \\
\\
\text { - Larinks ödemi } \\
\text { - İstirahatte dispne } \\
\text { - Taşikardi } \\
\text { - Düşük kan } \\
\text { - basınc1 } \\
\text { - } \text { Fasial ödem } \\
\text { - } \text { Bulantı } \\
\text { - Kusma } \\
\text { - Anarın ağrısı } \\
\text { Anaflaktik şok }\end{array}$ & $\begin{array}{l}\text { 6410-Alerji yönetimi } \\
\text { 6610-Risk tanılama } \\
\text { 3350-Solunum izlemi } \\
\text { 6680-Vital bulguları izleme } \\
\text { 6140-Kod yönetimi } \\
\text { Alerji Yönetimi I̧çin Hemşirelik Aktiviteleri } \\
\text { - Bilinen ilaç, besin, böcek, boya, kimyasal, } \\
\text { toz, polen, küf, tüy vb. alerjileri ve genel } \\
\text { reaksiyonları belirlenir. } \\
\text { - Hastaya ve yakınlarına nöral tüp defekti } \\
\text { (örneğin, spinal bifida ) veya konjenital } \\
\text { üriner durum (örneğin, ekstrofik mesane) } \\
\text { ve doğal kauçuk latekse sistemik reaksiyon } \\
\text { öyküsünün olup olmadığını sorulur. } \\
\text { - Hasta ve yakınlarına muz kivi, avokado, } \\
\text { mango ve kestane gibi yiyeceklere alerjisi } \\
\text { olup olmadığı sorulur. } \\
\text { - Gerektiğinde test için alerji uzmanına } \\
\text { yönlendirilir. } \\
\text { - Hastanın tıbbı kayıtlarına varsa alerji veya } \\
\text { riski kaydedilir. } \\
\text { - Hastanın alerjisini olduğunu gösteren kol } \\
\text { bandı takılır. } \\
\text { - Anti alerjik ilaçlar hazır bulundurulur. } \\
\text { - Alerji oluşturma riski olan bir maddenin } \\
\text { uygulanmasından sonra hasta en az } 30 \text { dk } \\
\text { izlenir } \\
\text { - Lateks önlemlerini belirten bir işaret } \\
\text { koyulur. } \\
\text { - Lateks içermeyen çevre sağlanır. } \\
\text { - Hasta ve ailesi lateks alerji risk faktörleri } \\
\text { yönünden bilgilendirilir. } \\
\text { - Enjeksiyon alerjisi uygun şekilde yönetilir } \\
\text { - Kan basıncı, kalp hızı ve solunum hızı } \\
\text { izlenir. }\end{array}$ \\
\hline $\begin{array}{l}\text { Anksiyete } \\
\text { Belirsiz spesifik } \\
\text { olmayan bir tehdide } \\
\text { karşı otonom sinir } \\
\text { sistemi aktive olan ve } \\
\text { huzursuzluk yasayan } \\
\text { birey ya da grubun } \\
\text { durumudur. }\end{array}$ & $\begin{array}{l}\text { - Diş çekimi } \\
\text { - Çene } \\
\text { operasyonları } \\
\text { - Diş restorasyonu } \\
\text { (dolgu,kanal } \\
\text { tedavisi) }\end{array}$ & $\begin{array}{l}\text { - Ağlama } \\
\text { (çocuk } \\
\text { hastalar) } \\
\text { - Tansiyon } \\
\text { yükselmesi } \\
\text { - Öfke } \\
\text { patlamaları }\end{array}$ & $\begin{array}{l}\text { 1211- Anksiyete } \\
\text { düzeyi } \\
\text { 1402-Anksiyetenin } \\
\text { öz kontrolü } \\
\quad \text { Anksiyete Düzeyi } \\
\text { İçin Bazl } \\
\text { Göstergeler } \\
\\
\quad \text { (1-5 arasl } \\
\text { puanlanır) } \\
\text { - Huzursuzluk } \\
\text { - Volta atma } \\
\text { - Elleri ovuşturma } \\
\text { - Sikıntı } \\
\text { - Tedirginlik } \\
\text { - Hzzlı nabız } \\
\text { - Yüksek kan } \\
\text { basınc1 }\end{array}$ & $\begin{array}{l}\text { 5820-Anksiyetenin azaltılması } \\
\text { 6040-Gevsseme terapisi } \\
\text { 5880-Sakinleştirme tekniği } \\
\text { 6680-Vital bulguları izleme } \\
\text { Anksiyetenin Azaltılması İçin Hemşirelik } \\
\text { Aktiviteleri } \\
\text { - Sakin ve güven verici bir yaklaşım } \\
\text { kullanılır. } \\
\text { - Hastadan beklenen davranış açık olarak } \\
\text { ifade edilir. } \\
\text { - Tüm işlemler, işlemler sırasında neler } \\
\text { hissedebileceği (soğukluk, batma, ağrı) } \\
\text { açıklanır. } \\
\text { - Stresli durum için empati yapıllır. } \\
\text { - Korkuyu azaltmak ve güvenliği } \\
\text { geliştirmek için hastanın yanında kalınır. } \\
\text { - Tedavi malzemeleri görüş alanının dışında } \\
\text { tutulur. } \\
\text { - Dikkat ve ilgiyle dinlenir. } \\
\text { - Duyguları, algıllamaları ve korkuları } \\
\text { sözelleştirmesi için cesaretlendirilir. } \\
\text { - Anksiyete düzeyindeki değiş̧imler izlenir. } \\
\text { - Gerilimi azaltmaya yönelik eğlence } \\
\text { aktiviteleri sağlanır. } \\
\text { - Tansiyon takibi yapıllır. }\end{array}$ \\
\hline
\end{tabular}


Tablo 1 (Devam). Ağız ve diş sağlığı sorunu olan hastaların hemşirelik bakımında ele alınması gereken hemşirelik tanıları (pes formatında), hemşirelik sonuçları ve hemşirelik girişimleri.

\begin{tabular}{|c|c|c|c|c|}
\hline $\begin{array}{l}\text { Hemşirelik } \\
\text { Tanısı }\end{array}$ & $\begin{array}{l}\text { Etiyolojik } \\
\text { faktörler }\end{array}$ & $\begin{array}{l}\text { Tanımlayıcı } \\
\text { özellikler }\end{array}$ & NOC sonuçları & NIC girişimleri \\
\hline $\begin{array}{l}\text { Aspirasyon riski } \\
\text { Trakeobronşial pasaja } \\
\text { sekresyonların katı } \\
\text { besinlerin ve siviların } \\
\text { kaçması riski bulunan } \\
\text { bir kişideki durumdur. }\end{array}$ & $\begin{array}{l}\text { Risk Faktörleri } \\
\\
\text { - Oral cerrahi ya da } \\
\text { travma } \\
\text { - Çene ateli, tel } \\
\text { takılması } \\
\text { - Ağız içi tedavisi } \\
\text { - Dentisyonun } \\
\text { /dişlerin uygun } \\
\text { olmaması }\end{array}$ & - & $\begin{array}{l}\text { 1918-Aspirasyonu } \\
\text { önleme } \\
\text { 1012-Yutma } \\
\text { durumu } \\
\text { 1902-Risk kontrolü } \\
\\
\text { Aspirasyonu Önleme } \\
\text { İçin Bazı Göstergeler } \\
\text { (1-5 arası puanlanır) } \\
\text { - Risk faktörlerini } \\
\text { tanımlar } \\
\text { - Risk faktörlerinden } \\
\text { kaçınır } \\
\text { - Yiyip içerken dik } \\
\text { konuma geçebilir } \\
\text { - Yutma becerisine } \\
\text { göre yiyecek seçer }\end{array}$ & $\begin{array}{l}\text { 3200-Aspirasyon önlemleri } \\
\text { 3160-Hava yolu aspirasyonu } \\
\text { 3140-Hava yolu yönetimi } \\
\text { 6610-Risk tanılama } \\
\text { Aspirasyon Önlemleri İçin Hemşirelik } \\
\text { Aktiviteleri } \\
\text { - İşlem öncesi hastanın oral kavitesi, } \\
\text { öksürme ve ögürme refleksi } \\
\text { değerlendirilir. } \\
\text { - Yutma güçlügü izlenir. } \\
\text { - Sedatif ve narkotik kullanma durumu } \\
\text { değerlendirilir. } \\
\text { - Havayolu açıklığı sürdürülür. } \\
\text { - Diş ünitesi sakşı setinin çalıı̧ıp } \\
\text { çalışmadığı kontrol edilerek hazır hale } \\
\text { getirilir. } \\
\text { - Sakssın kullanımı öğretilir. } \\
\text { - Tedavi sirasında kullanılmak üzere } \\
\text { sözsüz iletişim şekli belirlenir. } \\
\text { - Tedavi öncesi hastaya uygun poziyon } \\
\text { verilir. } \\
\text { - Ağız içi işlem sırasında ağızda biriken } \\
\text { sıvı aspire edilir. } \\
\text { - Ağı içi anestezi uygulamasından } \\
\text { sonra yeterli süre oral alım kısıtlanır } \\
\text { - Yiyecekleri küçük parçalar halinde } \\
\text { yemesi gerektiği açıklanır. } \\
\text { - Reflü şikayetleri varsa yemekten } \\
\text { sonra hemen yatmamas gerektiği } \\
\text { açıklanır. } \\
\text { - Kontrendike değilse yatak başını } \\
\text { yükselterek yatması gerektiği } \\
\text { açıklanır. }\end{array}$ \\
\hline $\begin{array}{l}\text { Bilgi Eksikliği } \\
\text { Tedavi planı ya da } \\
\text { durumla ilgili bilişsel } \\
\text { bilgi ve veya } \\
\text { psikomotor beceri } \\
\text { eksikliği olan bir } \\
\text { birey ya da gruptaki } \\
\text { durumdur. }\end{array}$ & $\begin{array}{l}\text { Tedavi ve bakım } \\
\text { planının günlük } \\
\text { aktivitelere entegre } \\
\text { edilememesi }\end{array}$ & $\begin{array}{l}\text { - Ağız kokusu } \\
\text { - Bozuk ağız hijyeni } \\
\text { - Erken diş kayıpları } \\
\text { - Yetersiz protez } \\
\text { bakımı }\end{array}$ & 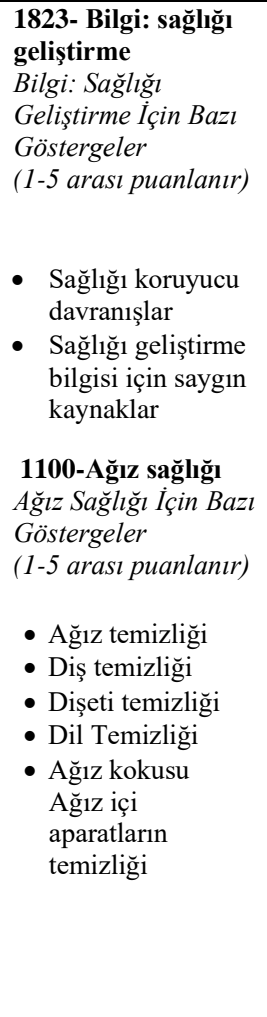 & $\begin{array}{l}\text { 5606-Öğretim: bireysel } \\
\text { Öğretim İçin Hemşirelik Aktiviteleri } \\
\text { Hastanın ağzı (dudaklar, dil, mukozalar, } \\
\text { dişler ve diş etleri) değerlendirilir. } \\
\text { Hastanın genel ağız hijyeni alışkanlığı } \\
\text { belirlenir. } \\
\text { Hastanın gelişim düzeyine ve öz bakım } \\
\text { becerisine göre diş ipi kullanma, diş } \\
\text { firçalama, ağız çalkalama, yeterli } \\
\text { beslenme, fluroid içeren su kullanma, } \\
\text { diğer koruyucu veya ek ürünler } \\
\text { kullanma konusunda öğretim yapılır } \\
\text { Protezi olan hastaya protezi çıkarma, } \\
\text { temizleme yeniden takma; diş etlerini, } \\
\text { kalan dişlerini ve dilini firçalama, } \\
\text { parmakları veya firça ile diş etlerine } \\
\text { masaj yapma konusunda öğretim yapılır } \\
\text { Hasta ve hasta yakınlarına uygun ağız } \\
\text { bakım ürünlerini tanıtllır ve temin } \\
\text { etmelerine yardım edilir. } \\
\text { Şekerin diş çürümesine etkisi açılanır, } \\
\text { sınırlı miktarda doğal şeker tüketmeye } \\
\text { teşvik edilir. } \\
\text { Tütün kullanımının etkileri, tütün } \\
\text { kullanmayı önlemeye yönelik tedbirler } \\
\text { konusunda bilgi verilir. Tütün } \\
\text { kullanımını bırakmaya yönelik yardım } \\
\text { sağlanır. } \\
\text { Düzenli diş kontrolü yaptırmanın } \\
\text { önemini açılanır. }\end{array}$ \\
\hline
\end{tabular}


Tablo 1 (Devam). Ağız ve diş sağlığı sorunu olan hastaların hemşirelik bakımında ele alınması gereken hemşirelik tanıları (pes formatında), hemşirelik sonuçları ve hemşirelik girişimleri.

\begin{tabular}{|c|c|c|c|c|}
\hline $\begin{array}{l}\text { Hemşirelik } \\
\text { Tanısı }\end{array}$ & $\begin{array}{l}\text { Etiyolojik } \\
\text { faktörler }\end{array}$ & $\begin{array}{l}\text { Tanımlayıcı } \\
\text { özellikler }\end{array}$ & $\begin{array}{l}\text { NOC } \\
\text { sonuçları }\end{array}$ & NIC girişimleri \\
\hline $\begin{array}{l}\text { Beden imajinda } \\
\text { bozulma } \\
\text { Fiziksel olarak kendini } \\
\text { (fiziksel görünümünü) } \\
\text { algllayış şeklinde bir } \\
\text { kargaşa yaşayan ya da bu } \\
\text { riski taşıan bir } \\
\text { bireydeki durumdur. }\end{array}$ & $\begin{array}{l}\text { - Diş kayıpları } \\
\text { - Yüzde şekil } \\
\text { bozukluğu } \\
\text { - Uygun olmayan } \\
\text { protezler }\end{array}$ & $\begin{array}{l}\text { - Bireyin algılanan } \\
\text { durumunu sözel } \\
\text { veya sözel olmayan } \\
\text { olumsuz tepkilerle } \\
\text { göstermesi } \\
\text { - Yüzüne } \\
\text { bakamaması } \\
\text { - Yüzünü gizlemeye } \\
\text { çalışması }\end{array}$ & \begin{tabular}{|l} 
1200-Beden imajı \\
1300- \\
Kabullenme \\
1302-Başa çıkma \\
\\
Beden İmajı İçin \\
Bazı Göstergeler \\
(1-5 arası \\
puanlanır) \\
- Görünümü \\
geliştirmek için \\
stratejiler \\
kullanmaya \\
yönelik tutum \\
- Fiziksel \\
görünümündeki \\
değişikliğe alışma \\
- Sağlık \\
durumundaki \\
değişikliğe alışma \\
- Yaşlanma \\
nedeniyle vücut \\
değişikliğine \\
uyum
\end{tabular} & $\begin{array}{l}\text { 5220-Beden imgesini güçlendirme } \\
\text { 4920-Aktif dinleme } \\
\text { 5230-Baş etmeyi güçlendirme } \\
\text { 5240-Danışmanlık } \\
\text { 5250-Karar vermeyi destekleme } \\
\text { Beden Imgesini Güçlendirme İçin } \\
\text { Hemşirelik Aktiviteleri } \\
\text { - Duygularını, düşüncelerini, kendine } \\
\text { bakış açısını ifade etmesi için } \\
\text { cesaretlendirilir. } \\
\text { - Tedavi ve gelişmeler konusunda soru } \\
\text { sorması için cesaretlendirilir. } \\
\text { - Güvenli bilgi verilir ve pekiştirilir. } \\
\text { - Uygun olmayan protezlerle ilgili } \\
\text { hastanın şaşkınlık, öfke, içe kapanma } \\
\text { şeklindeki tepkilerine hazır olunur } \\
\text { - Olanaklar, alternatifler ve güçlü } \\
\text { yönler birey ile birlikte ortaya } \\
\text { çıarılır. }\end{array}$ \\
\hline $\begin{array}{l}\text { Beden gereksiniminden } \\
\text { az beslenme } \\
\text { Ağızdan beslenmesinde } \\
\text { bir engel olmayan } \\
\text { (oral almama durumu } \\
\text { olmayan), kilo kaybı ile } \\
\text { birlikte ya da kilo kaybı } \\
\text { olmaksızın, metobolik } \\
\text { gereksinimlerine göre } \\
\text { besin alınımı ya da } \\
\text { metobolizması yetersiz } \\
\text { kalan bir bireydeki } \\
\text { durumdur. }\end{array}$ & $\begin{array}{l}\text { - Çene ateli } \\
\text { - Ağızda cerrahi } \\
\text { rekonstrüksiyonla } \\
\text { r1 } \\
\text { - Diş kaybı } \\
\text { - Protez } \\
\quad \text { kullanımına bağlı } \\
\text { stomatitler } \\
\text { - Ağrı }\end{array}$ & $\begin{array}{l}\text { - Önerilen günlük } \\
\text { miktardan daha az / } \\
\text { yetersiz besin } \\
\text { alması }\end{array}$ & $\begin{array}{l}\begin{array}{l}\text { 1009- Beslenme } \\
\text { durumu:Besin } \\
\text { alımı }\end{array} \\
\text { 1006-Kilo: Beden } \\
\text { kitlesi } \\
\text { Beslenme } \\
\text { durumu:Besin } \\
\text { alımı İçin Bazı } \\
\text { Göstergeler } \\
\text { (1-5 arası } \\
\text { puanlanır) } \\
\text { - Kalori alımı } \\
\text { - Protein alımı } \\
\text { - Yağ alımı } \\
\text { - Karbonhidrat } \\
\text { alımı } \\
\text { - Lif alımı } \\
\text { - Vitamin alımı } \\
\text { - Mineral alımı } \\
\text { - Demir alımı } \\
\text { - Kalsiyum alımı }\end{array}$ & $\begin{array}{l}\text { 5246-Beslenme danışmanlı̆̆ı } \\
\text { 5606-Öğretim: Bireysel } \\
\text { 1400-Ağrı yönetimi } \\
\text { 2210-Analjezik uygulaması } \\
\text { Beslenme Danışmanlı̆ğ Hemşirelik } \\
\text { Aktiviteleri } \\
\text { - Uygun bir şekilde beslenme } \\
\text { değerlendirmesi yapılır. } \\
\text { - Hastanın besin tercihleri belirlenir. } \\
\text { - Hastanın beslenme planlaması } \\
\text { hazırlanırken yaş, büyüme gelişme } \\
\text { dönemi, yeme sonrası deneyimleri, } \\
\text { kültür ve ekonomik durum gibi } \\
\text { faktörler göz önünde bulundurulur. } \\
\text { - Beslenme gereksinimlerini } \\
\text { karşılayacak besin tipleri ve kalori } \\
\text { miktarları tanımlanır. } \\
\text { - Yemeklerden önce ağı hijyeni } \\
\text { sağlanır. } \\
\text { - Gerekirse yemeklerden önce hastanın } \\
\text { ağrı kesici alması sağlanır. } \\
\text { - Hastanın hafif, yumuşak ve asidik } \\
\text { olmayan gıdaları seçebilmesine } \\
\text { yardımcı olunur. } \\
\text { - Uygunsa hastanın protezlerini takması } \\
\text { sağlanır. } \\
\text { - Protez kullanan hastalara protez } \\
\text { bakımı hakkında bilgi verilir. } \\
\text { - Protez ihtiyacı olan hastalar uygun } \\
\text { birimlere gitmesi yönünde } \\
\text { bilgilendirilir. }\end{array}$ \\
\hline
\end{tabular}


Tablo 1 (Devam). Ağız ve diş sağı̆̆̆ı sorunu olan hastaların hemşirelik bakımında ele alınması gereken hemşirelik tanıları (pes formatında), hemşirelik sonuçları ve hemşirelik girişimleri.

\begin{tabular}{|c|c|c|c|c|}
\hline $\begin{array}{l}\text { Hemşirelik } \\
\text { Tanısı }\end{array}$ & $\begin{array}{l}\text { Etiyolojik } \\
\text { faktörler }\end{array}$ & $\begin{array}{l}\text { Tanımlayıcı } \\
\text { özellikler }\end{array}$ & $\begin{array}{l}\text { NOC } \\
\text { sonuçları }\end{array}$ & NIC girişimleri \\
\hline $\begin{array}{l}\text { Boğazın arkasında, } \\
\text { epigastriumda veya } \\
\text { tüm abdomende } \\
\text { tatsız dalgalanma } \\
\text { halinde ortaya çıkan, } \\
\text { kusma ile } \\
\text { sonuçlanan ya da } \\
\text { kusma olmaksızın } \\
\text { kusacağı duygusu } \\
\text { yaşayan bir } \\
\text { bireydeki durumdur. }\end{array}$ & $\begin{array}{l}\text { - Ağız içi tedavi } \\
\text { esnasında ağızda } \\
\text { sıvı birikmesi } \\
\text { - İlaçlar, anestezi } \\
\text { ve dolgu } \\
\text { materyalleri }\end{array}$ & \begin{tabular}{|l} 
Solgunluk ve \\
soğukluk \\
Hasta bireyin bulantısı \\
olduğunu söylemesi \\
ve sonrasında kusma \\
yaşanması
\end{tabular} & $\begin{array}{l}\text { 1618- Bulantı- } \\
\text { kusma kontrolü } \\
\text { 2010- Rahatlık } \\
\text { durumu: Fiziksel } \\
\\
\text { Bulantı-kusma } \\
\text { kontrolü İcin Bazı } \\
\text { Göstergeler } \\
\text { (1-5 arası } \\
\text { puanlanır) } \\
\\
\text { - Bulantı } \\
\text { başlangıcını } \\
\text { tanır } \\
\text { - Neden olan } \\
\text { faktörleri } \\
\text { tanımlar } \\
\text { - Tetikleyici } \\
\text { uyaranları } \\
\text { tanımlar } \\
\text { - Antiemetik } \\
\text { ilaçları } \\
\text { önerildiği } \\
\text { şekilde kullanır }\end{array}$ & $\begin{array}{l}\text { 1570-Kusma yönetimi } \\
\text { 3200-Aspirasyon önlemleri } \\
\text { 5900-Dikkati başka yöne çekme } \\
\text { 2380-İlaç tedavisinin uygulanması } \\
\text { Kusma Yönetimi Hemşirelik Aktiviteleri } \\
\\
\text { - Tedavi öncesi tam öykü alınır. } \\
\text { - Bulantıya eşlik eden ve artıran bireysel } \\
\text { faktörler (anksiyete, korku) azaltılır ya da } \\
\text { ortadan kaldırılır. } \\
\text { Bulantıya neden olabilecek ya da katkıda } \\
\text { bulunabilecek faktörler (ilaçlar ve işlemler) } \\
\text { belirlenir. } \\
\text { Bulantıy önlemek için non-farmakolojik } \\
\text { yöntemlerin (dikkati başka yöne çekme, } \\
\text { gevşeme) kullanımı öğretiliir. } \\
\text { Tedavi esnasında ağızda biriken sıvı sık sık } \\
\text { aspire edilir. } \\
\text { İşlem esnasında ara ara dinlenmesi ve } \\
\text { rahatlaması săglanır. } \\
\text { Bulantının sebebi ve ne kadar sürede } \\
\text { geçeceği gibi konularda bilgi sağlanır. } \\
\text { Bulantıyı önlemek için hekim önerisi } \\
\text { doğrultusunda antiemetik ilaç verilir. } \\
\text { Ortam havalandırılır. }\end{array}$ \\
\hline $\begin{array}{l}\begin{array}{l}\text { Dentisyonda } \\
\text { (dişlenmede) } \\
\text { bozukluk }\end{array} \\
\text { Diş } \\
\text { gelişiminde/dişlerin } \\
\text { çıkma örüntülerinde } \\
\text { ya da dişlerin } \\
\text { yapısal } \\
\text { bütünlüğünde } \\
\text { bozulma olan bir } \\
\text { bireydeki durumdur. }\end{array}$ & $\begin{array}{l}\text { - Genetik } \\
\text { faktörlerle } \\
\text { dişlerin yapısının } \\
\text { zayıf olması. } \\
\text { - Bebeklikte oluşan } \\
\text { diş bozuklukları } \\
\text { - Fazla şekerli ve } \\
\text { asitli yiyeceklerin } \\
\text { tüketilmesi } \\
\text { - Diş } \\
\text { muayenelerini } \\
\text { aksatmak ya da } \\
\text { hiç gitmemek. } \\
\text { - Ağız içerisinde } \\
\text { eksik diş olması } \\
\text { - Diş gıcırdatma } \\
\text { - Özbakım } \\
\text { engelleri } \\
\text { - Kötü beslenme } \\
\text { - Kronik kusma } \\
\text { - Bazı ilaçlar }\end{array}$ & $\begin{array}{l}\text { - Dişlerde çürük } \\
\text { oluşması } \\
\text { - Plak oluşumu } \\
\text { - Ağız içerisinde } \\
\text { koku oluşması } \\
\text { - Dişlerin eksik } \\
\text { olması ya da tam } \\
\text { yokluğu } \\
\text { - Dişlerin renginin } \\
\text { sararması } \\
\text { - Diş eti şişlikleri } \\
\text { - Diş tartarı (diş taşı) } \\
\text { oluşumu } \\
\text { - Asimetrik yüz } \\
\text { görünümü } \\
\text { - Süt dişlerinin erken } \\
\text { kaybı } \\
\text { - Diş minesinde } \\
\text { aşnma } \\
\text { - Diş kırıkları } \\
\text { - Alt ve üst çene } \\
\text { arsında temas } \\
\text { bozukluğu, dişin } \\
\text { kötü yerleşimi } \\
\text { - Beden imajında } \\
\text { bozulma }\end{array}$ & $\begin{array}{l}\text { 1100-Ağız sağı̆̆ğ } \\
\text { 1009- Beslenme } \\
\text { durumu:Besin } \\
\text { alınımı } \\
\text { A ğız Sağllğı İçin } \\
\text { Bazı Göstergeler } \\
\text { (1-5 arası } \\
\text { puanlanır) }\end{array}$ & 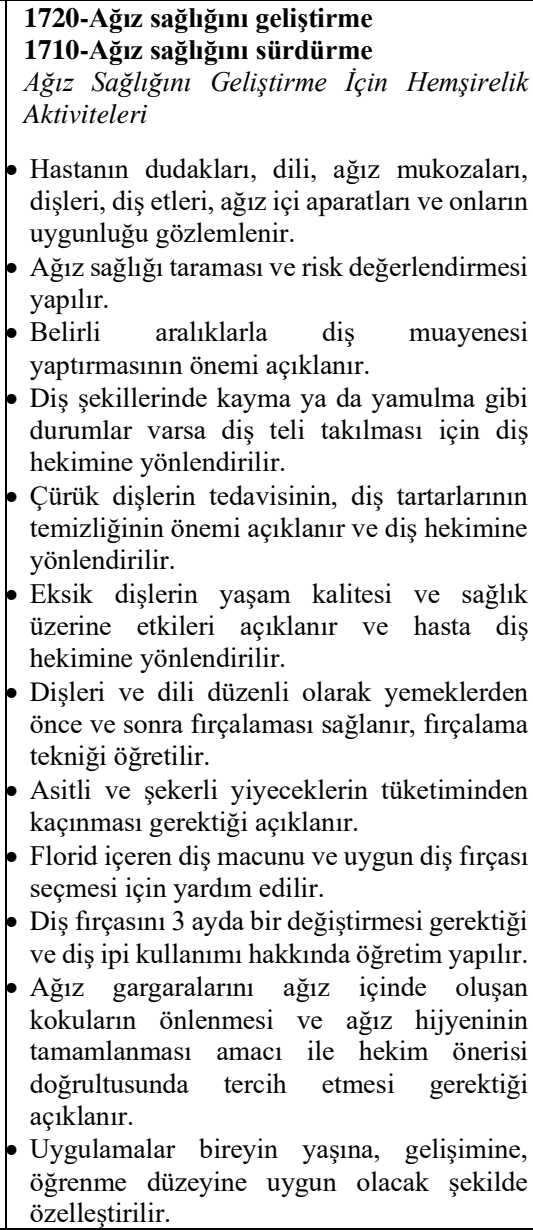 \\
\hline
\end{tabular}


Tablo 1 (Devam). Ağız ve diş sağı̆̆̆ı sorunu olan hastaların hemşirelik bakımında ele alınması gereken hemşirelik tanıları (pes formatında), hemşirelik sonuçları ve hemşirelik girişimleri.

\begin{tabular}{|c|c|c|c|c|}
\hline $\begin{array}{l}\text { Hemşirelik } \\
\text { Tanısı }\end{array}$ & $\begin{array}{l}\text { Etiyolojik } \\
\text { faktörler }\end{array}$ & $\begin{array}{l}\text { Tanımlayıcı } \\
\text { özellikler }\end{array}$ & $\begin{array}{l}\text { NOC } \\
\text { sonuçları }\end{array}$ & NIC girişimleri \\
\hline $\begin{array}{l}\text { Düşük benlik saygısı } \\
\\
\text { Önceden olumlu bir } \\
\text { benlik saygısına sahip } \\
\text { iken, bir olaya / duruma } \\
\text { tepki olarak kendisi } \\
\text { hakkında negatif } \\
\text { duygular yaşayan bir } \\
\text { bireydeki durumdur. }\end{array}$ & $\begin{array}{l}\text { - Diş kayıpları } \\
\text { - Uygun olmayan } \\
\text { protezler } \\
\text { - Uygun olmayan ağız } \\
\text { hijyeni } \\
\text { - Olumsuz geri } \\
\text { bildirim }\end{array}$ & $\begin{array}{l}\text { Daha önce } \\
\text { kendisini olumlu } \\
\text { değerlendiren } \\
\text { kişinin yaşanan } \\
\text { duruma karşı } \\
\text { olumsuz } \\
\text { değerlendirme } \\
\text { yapması } \\
\text { - Kendi duygularını } \\
\text { olumsuz olacak } \\
\text { şekilde ifade } \\
\text { etmesi } \\
\text { - Sosyal izolasyon } \\
\text { - Hastanın } \\
\text { kendine önem } \\
\text { vermemesi, kendini } \\
\text { sürekli ihmal } \\
\text { etmesi }\end{array}$ & $\begin{array}{l}\text { 1205-Benlik } \\
\text { saygısı } \\
\text { Benlik Saygısı Iç̧in } \\
\text { Bazı Göstergeler } \\
\text { (1-5 arası } \\
\text { puanlanır) } \\
\text { - Öz kabulün } \\
\text { sözel ifadesi } \\
\text { - Öz } \\
\text { sınırlılıkların } \\
\text { kabulü } \\
\text { - Göz temasını } \\
\text { sürdürme } \\
\text { - Açık iletişim } \\
\text { - Yapııcı } \\
\text { eleştirinin } \\
\text { kabulü } \\
\text { - Güven düzeyi }\end{array}$ & $\begin{array}{l}\text { 5400-Benlik saygısını güçlendirme } \\
\text { 4920-Aktif dinleme } \\
\text { 5230-Baş etmeyi güçlendirme } \\
\text { 5240-Danışmanık } \\
\text { 5330-Duygu durum yönetimi } \\
\text { 5250-Karar vermeyi destekleme } \\
\text { Benlik Saygısını Güçlendirme İçin } \\
\text { Hemşirelik Aktiviteleri } \\
\text { - Hastanın kendine verdiği değere } \\
\text { ilişkin ifadeleri gözlemlenir. } \\
\text { - Olumsuz eleştiriden kaçınılır. } \\
\text { - Olumsuz otomatik düşünceleri } \\
\text { tanımasına yardım ediniz. } \\
\text { - Başkalarından gelen olumlu } \\
\text { tepkileri tanıasına yardımcı } \\
\text { olunur. Gün } \\
\text { - Güçlü yönlerini tanımasında bireye } \\
\text { yardım edilir. } \\
\text { - Kendini kabullenmesi için hastaya } \\
\text { yardım edilir. } \\
\text { - Daha yüksek benlik saygısı } \\
\text { oluşturabilmek için ulaşılabilir } \\
\text { geçekçi hedefler belirlemesine } \\
\text { yardım edilir. } \\
\text { - Hastanın otonomisini artıracak } \\
\text { uygun deneyimler sağlanır. }\end{array}$ \\
\hline $\begin{array}{l}\text { Enfeksiyon riski } \\
\text { Endojen ve ekzojen } \\
\text { kaynaklı, firsatçı yada } \\
\text { potojen bir ajanın (virüs, } \\
\text { fungus, bakteri protozoa } \\
\text { ya da diğer parazitler) } \\
\text { hücumuna uğrama riski } \\
\text { taşıyan bir bireydeki } \\
\text { durumdur. }\end{array}$ & $\begin{array}{l}\text { Risk Faktörleri } \\
\text { - Ağız diş çene } \\
\text { operasyonları } \\
\text { - Tedaviyle ilgili } \\
\text { invaziv girişimler }\end{array}$ & - & $\begin{array}{l}\text { 1924-Risk } \\
\text { kontrolü: } \\
\text { Enfeksiyon } \\
\text { süreci } \\
\\
\text { Risk kontrolü: } \\
\text { Enfeksiyon süreci } \\
\text { İ̧̧in Bazı } \\
\text { Göstergeler } \\
\text { (1-5 arası } \\
\text { puanlanır) } \\
\\
\text { - Enfeksiyon için } \\
\text { güncel bilgi } \\
\text { arar } \\
\text { - Enfeksiyon için } \\
\text { kişisel risklerini } \\
\text { bilir } \\
\text { - Enfeksiyon } \\
\text { riski ile ilişkili } \\
\text { davranışları } \\
\text { bilir }\end{array}$ & $\begin{array}{l}\text { 6550-Enfeksiyondan koruma } \\
\text { 6610-Risk tanılama } \\
\\
\text { Enfeksiyondan Koruma Iç̧in } \\
\text { Hemşirelik Aktiviteleri } \\
\text { - Enfeksiyonun lokal ve sistemik } \\
\text { belirtileri izlenir. } \\
\text { - Riskli hastada asepsi sürdürülür } \\
\text { - Enfeksiyona yatkınlık izlenir } \\
\text { - Küresel seyahat öyküsü izlenir } \\
\text { - Granülosit sayısı, lökosit sayısı, } \\
\text { periferik yayma sonuçları izlenir } \\
\text { - Nötropenik önlemler alınır. } \\
\text { - Bağışıllk durumu değerlendirilir. } \\
\text { - Gerektiğinde kültür alınır } \\
\text { - Yeterli besin alımı sağlanır. } \\
\text { - Sivı alımı teşvik edilir } \\
\text { - Gerektiğinde özel oda sağlanır } \\
\text { - İçme suyu güvenliği sağlanır. } \\
\text { - İstem edilen antibiyotikler uygun } \\
\text { şekilde verilir } \\
\text { - İlaç kullanımı hakkında öğretim } \\
\text { yapıllır. }\end{array}$ \\
\hline
\end{tabular}


Tablo 1 (Devam). Ağız ve diş sağlığı sorunu olan hastaların hemşirelik bakımında ele alınması gereken hemşirelik tanıları (pes formatında), hemşirelik sonuçları ve hemşirelik girişimleri.

\begin{tabular}{|c|c|c|c|c|}
\hline $\begin{array}{l}\text { Hemşirelik } \\
\text { Tanısı }\end{array}$ & $\begin{array}{l}\text { Etiyolojik } \\
\text { faktörler }\end{array}$ & $\begin{array}{l}\text { Tanımlayıcı } \\
\text { özellikler }\end{array}$ & NOC sonuçları & NIC girişimleri \\
\hline $\begin{array}{l}\text { Enfeksiyon } \\
\text { bulaştirma riski } \\
\text { Patojen ya da } \\
\text { firsatçı bir ajanı } \\
\text { başkalarına geçirme } \\
\text { / bulaştırma riski } \\
\text { taşıyan bir bireydeki } \\
\text { durumdur. }\end{array}$ & $\begin{array}{l}\text { Risk Faktörleri } \\
\text { - Kontamine } \\
\text { drenajdaki ve } \\
\text { tedavi sırasında } \\
\text { kullanılan diğer } \\
\text { araçlara bağlı } \\
\text { (Örneğin, } \\
\text { aspirasyon aleti) } \\
\text { - Hijyenik olmayan } \\
\text { tedavi ortamı } \\
\text { - Bulaşıcı hastalık } \\
\text { varlığı }\end{array}$ & - & $\begin{array}{l}\text { 1924-Risk } \\
\text { kontrolü: } \\
\text { Enfeksiyon süreci } \\
\text { Risk kontrolü: } \\
\text { Enfeksiyon süreci } \\
\text { Için Bazl } \\
\text { Göstergeler } \\
\text { (1-5 arası } \\
\text { puanlanır) } \\
\text { - Temiz bir çevre } \\
\text { sürdürür } \\
\text { - El hijyeni } \\
\text { uygular } \\
\text { - Evrensel } \\
\text { önlemleri alır } \\
\text { • Enfeksiyon } \\
\text { kontrolü } \\
\text { stratejilerini } \\
\text { uygular }\end{array}$ & $\begin{array}{l}\text { 6540-Enfeksiyon kontrolü } \\
\text { 6610-Risk tanılama } \\
\text { Enfeksiyon Kontrolü Iç̧in Hemşirelik } \\
\text { Aktiviteleri } \\
\text { Hastadan tam öykü alınır. } \\
\text { Bulaşıcı hastalığı olan hastalara yönelik } \\
\text { koruyucu önlemler alınır. } \\
\text { Hastalık Kontrol ve Önleme Merkezi } \\
\text { (The Centers for Disease Control and } \\
\text { Prevention- CDC) tarafından belirtildiği } \\
\text { gibi hasta başına uygun metre kare alan } \\
\text { ayırılır. } \\
\text { Her hasta kullanımından sonra çevre } \\
\text { uygun biçimde temizlenir. } \\
\text { Hasta takım araçları kurum protokolüne } \\
\text { göre değiştirilir. } \\
\text { İnvaziv işlemler aseptik yöntemle yapılır. } \\
\text { Sağlık çalışanına, öğrencilere ve hastaya el } \\
\text { yıkama ve hijyeni hakkında öğretim } \\
\text { yapılır. } \\
\text { Her hasta bakım aktivitesinden önce ve } \\
\text { sonra eller yıkanır. } \\
\text { Evrensel önlemler uygulanır ve evrensel } \\
\text { önlemler politikasına uygun olarak } \\
\text { eldiven giyilir } \\
\text { Steril eldiven gerekli durumlarda ve uygun } \\
\text { şekilde giyinilir. } \\
\text { Hastaya ve ailesine enfeksiyon belirti ve } \\
\text { bulguları öğretilir. }\end{array}$ \\
\hline $\begin{array}{l}\text { Etkisiz Cinsellik } \\
\text { Cinsel sağlığında bir } \\
\text { değişim yaşayan ya } \\
\text { da bu riski taşıyan } \\
\text { bir bireydeki } \\
\text { durumdur. }\end{array}$ & $\begin{array}{l}\text { - Yetersiz ağız } \\
\text { hijyeni } \\
\text { - Ağıda kötü koku } \\
\text { olması } \\
\text { - Beden imajında } \\
\text { bozulma } \\
\text { - Hastalık ya da } \\
\text { tıbbi tedavi }\end{array}$ & $\begin{array}{l}\text { - Eşile ilişkilerinde } \\
\text { değişiklik } \\
\text { - Cinsel aktivite ve } \\
\text { davranışlarında } \\
\text { değişiklik } \\
\text { bildirmesi }\end{array}$ & $\begin{array}{l}\text { 0119- Cinsel işlev } \\
\text { 1100-Ağız sağlığı } \\
\text { Cinsel işlev İçin } \\
\text { Bazı Göstergeler } \\
\text { (1-5 arası } \\
\text { puanlanır) } \\
\text { - Benlik saygısını } \\
\text { ifade eder } \\
\text { - Partneri ile rahat } \\
\text { iletişim kurar } \\
\text { - Partnerine } \\
\text { saygılıdır }\end{array}$ & $\begin{array}{l}\text { 5248-Cinsel danışmanlık } \\
\text { 1710-Ağız sağlığını sürdürme } \\
\text { 5400-Benlik saygısını güçlendirme } \\
\text { Cinsel Danışmanlık İçin Hemşirelik } \\
\text { Aktiviteleri } \\
\text { - Hastayla güven ve saygıya dayalı bir } \\
\text { iletişim kurulur. } \\
\text { - Danışmanlık ilişkisinin süresi belirlenir. } \\
\text { - Hasta mahremiyetine özen gösterilerek } \\
\text { elde edilen bilgilerin gizli tutulacağına } \\
\text { dair güven verilir } \\
\text { - Hastanın genel olarak cinsellikle ilgili } \\
\text { bilgi düzeyi belirlenir. } \\
\text { - Eşlerin ayrı ayrı fikir ve görüşlerini ifade } \\
\text { etmesi sağlanır. } \\
\text { - Cinsellik ve cinsel fonksiyonlarla ilgili } \\
\text { rahatsız eden konularda soru sorması için } \\
\text { hasta cesaretlendirilir. } \\
\text { - Konuşmaya en az hassas ola konulardan } \\
\text { başlanılır. } \\
\text { - Endişelerin ifade edilmesini } \\
\text { kolaylaştırmak için yansıtma ve açığa } \\
\text { kavuşturma teknikleri kullanılır. } \\
\text { - Ağız kokusuna neden olan faktör } \\
\text { belirlenerek uygun tedavi yapılması } \\
\text { sağlanır. } \\
\text { - Her yemekten önce ve sonra dişlerini } \\
\text { fırçalamasının önemi açıklanır. } \\
\text { - Protez kullanıyorsa protez bakımı ve } \\
\text { kontrolleri öğretilir. } \\
\text { Çürük ve eksik dişlerin tedavisi için diş } \\
\text { hekimine yönlendirilir. } \\
\text { - Hekim önerisi ile ağız iç̧inde oluşan } \\
\text { kokuların önlenmesi için ağız gargaraları } \\
\text { verilir. }\end{array}$ \\
\hline
\end{tabular}


Tablo 1 (Devam). Ağız ve diş sağlığı sorunu olan hastaların hemşirelik bakımında ele alınması gereken hemşirelik tanıları (pes formatında), hemşirelik sonuçları ve hemşirelik girişimleri.

\begin{tabular}{|c|c|c|c|c|}
\hline $\begin{array}{l}\text { Hemşirelik } \\
\text { Tanısı }\end{array}$ & $\begin{array}{l}\text { Etiyolojik } \\
\text { faktörler }\end{array}$ & $\begin{array}{l}\text { Tanımlayıcı } \\
\text { özellikler }\end{array}$ & $\begin{array}{l}\text { NOC } \\
\text { sonuçları }\end{array}$ & NIC girişimleri \\
\hline $\begin{array}{l}\text { Kanama riski } \\
\text { Cerrahi bir işlem ya da } \\
\text { invaziv bir girişim } \\
\text { sonucunda damar } \\
\text { bütünlüğunün bozulma } \\
\text { riski taşıyan bir } \\
\text { bireydeki durumdur. }\end{array}$ & $\begin{array}{ll} & \text { Risk Faktörleri } \\
& \\
\text { - } & \text { Antikoagülan ilaç } \\
\text { kullanımı, } \\
\text { - Kullanılan ağrı kesici } \\
\text { ilaçlar } \\
\text { - Alkol ve uyuşturucu } \\
\text { madde kullanımı } \\
\text { - Kan hastalıkları } \\
\text { - Kalp rahatsızlığı ve } \\
\text { tansiyon varlığı } \\
\text { - Travma ve tedaviye } \\
\text { bağlı yan etkiler }\end{array}$ & - & $\begin{array}{l}\text { 0413-Ciddi kan } \\
\text { kaybı } \\
\text { 1902-Risk } \\
\text { kontrolü } \\
\\
\text { Ciddi Kan Kaybı } \\
\text { İ̧in Bazı } \\
\text { Göstergeler } \\
\text { (1-5 arası } \\
\text { puanlanır) } \\
\\
\text { - Görünür kan } \\
\text { kaybı } \\
\text { - Ameliyat } \\
\text { sonrası kanama } \\
\text { - Deri ve müköz } \\
\text { membranlarda } \\
\text { solukluk } \\
\text { - Düşük } \\
\text { hemoglobin }\end{array}$ & $\begin{array}{l}\text { 4020-Kanamayı azaltma } \\
\text { 6610-Risk tanılama } \\
\text { 5616- Öğretim: tanımlanmış ilaç } \\
\text { tedavisi, işlem /tedavi } \\
\text { Kanamayı Azaltma İçin Hemşirelik } \\
\text { Aktiviteleri } \\
\text { - Yapılacak işlem öncesi ve sonrası } \\
\text { hemoglobin/hemotokrit } \\
\text { düzeyleri kontrol edilir. } \\
\text { - Koagülasyon/ pihtılaşma } \\
\text { çalışmalarını; protrombin zamanı } \\
\text { (PT), parsiyel trombublastin } \\
\text { zamanı (PTZ), fibronejen fibrinin } \\
\text { azalması , trombosit sayımı } \\
\text { sonuçları izlenir. } \\
\text { - Hasta kanama yönünden } \\
\text { yakından izlenir. } \\
\text { - İşlem öncesi aspirin, antikuagülan } \\
\text { vb. ilaçlardan kaçınması gerektiği } \\
\text { açılanır. } \\
\text { - Yaşam bulguları takip edilir. } \\
\text { - Etkilenen bölgeye uygun şekilde } \\
\text { buz paketi uygulanır. } \\
\text { - Ağı bakımı için yumuşak diş } \\
\text { firçası ve diş bakım ürünlerini } \\
\text { kullanması gerektiği açıklanır. } \\
\text { - Gerekirse tranfüzyon için uygun } \\
\text { kan ürünleri hazır bulundurulur. }\end{array}$ \\
\hline $\begin{array}{l}\text { Korku } \\
\text { Tehlikeli olarak } \\
\text { algılanan, tanınabilen bir } \\
\text { kaynağa ilişkin olarak } \\
\text { fizyolojik yada } \\
\text { emosyonel olarak bir } \\
\text { rahatsızlık duygusu } \\
\text { yaşayan bir birey ya da } \\
\text { bir gruptaki durumdur. }\end{array}$ & $\begin{array}{l}\text { - Diş çekimi } \\
\text { - Ağız diş-çene } \\
\text { operasyonu }\end{array}$ & $\begin{array}{l}\text { - Ağlama, kaçma, } \\
\text { terleme } \\
\text { - Huzursuzluk } \\
\text { - Öfke } \\
\text { - Bulantı } \\
\text { - Vital bulgularda } \\
\text { değişim } \\
\text { - Sik sik soru sorma }\end{array}$ & $\begin{array}{l}\text { 1210-Korku } \\
\text { düzeyi } \\
\text { Korku düzeyi } \\
\text { Ícin Bazı } \\
\text { Göstergeler } \\
\text { (1-5 arası } \\
\text { puanlanır) } \\
\\
\text { - Sıkıntı } \\
\text { - Sinirlilik } \\
\text { - Baygınlık } \\
\text { hissetmek } \\
\text { - Huzursuzluk } \\
\text { - Ağlama } \\
\text { - Baskalarını } \\
\text { suçlama eğilimi } \\
\text { - Öfke dışa } \\
\text { vurumu }\end{array}$ & $\begin{array}{l}\text { 5880-Sakileştirme tekniği } \\
\text { 5270-Emosyonel destek } \\
\text { 6040-Gevşeme terapisi } \\
\text { Sakinlesstirme Tekniği İ̧̧in } \\
\text { Hemşirelik Aktiviteleri } \\
\text { - Basit açıklamalar yaparak } \\
\text { çevreye uyumu sağlanır. } \\
\text { - Hastayla oturulur ve konuşulur. } \\
\text { - Hasta ile göz teması sürdürülür. } \\
\text { - Yavaşs sakin, basit kısa ifadeler } \\
\text { kullanılır. } \\
\text { - Duygularını ifade etmesi için } \\
\text { cesaretlendirilir. } \\
\text { - Hasta yalnız bırakılmaz, } \\
\text { - Varlığı ile hastaya yardımcı } \\
\text { olabilecek yakınları belirlenir. } \\
\text { - Gevşeme teknikleri (derin } \\
\text { soluk alıp verme, progresif kas } \\
\text { gevşetme gibi), dikkati başka } \\
\text { yöne çekme teknikleri (müzik } \\
\text { dinleme, hayal kurma gibi) } \\
\text { uygulanır. } \\
\text { - Hastanın soru sormasına firsat } \\
\text { verilir. }\end{array}$ \\
\hline
\end{tabular}


Tablo 1 (Devam). Ağız ve diş sağlığı sorunu olan hastaların hemşirelik bakımında ele alınması gereken hemşirelik tanıları (pes formatında), hemşirelik sonuçları ve hemşirelik girişimleri.

\begin{tabular}{|c|c|c|c|c|}
\hline $\begin{array}{l}\text { Hemşirelik } \\
\text { Tanısı }\end{array}$ & $\begin{array}{l}\text { Etiyolojik } \\
\text { faktörler }\end{array}$ & $\begin{array}{l}\text { Tanımlayıcı } \\
\text { özellikler }\end{array}$ & NOC sonuçları & NIC girişimleri \\
\hline $\begin{array}{l}\text { Oral müköz } \\
\text { membranlarda bozukluk } \\
\text { Oral kavitede bir değişim } \\
\text { /hasar bulunan ya da bu } \\
\text { riski taşıyan bir bireydeki } \\
\text { durumdur. }\end{array}$ & $\begin{array}{ll}\text { - } & \text { Yetersiz ağız } \\
& \text { hijyeni } \\
\text { - } & \text { Bilgi eksikliği } \\
\text { - } & \text { Sigara, alkol } \\
\text { kullanımı, asitli } \\
\text { içecekler } \\
\text { - İlaçlar } \\
\text { - Salivasyonda } \\
\text { azalma } \\
\text { - Kırılmış ya da } \\
\text { çentikli- sivri uçlu } \\
\text { dişler } \\
\text { - } \quad \text { Uyumsuz protezler }\end{array}$ & $\begin{array}{l}\text { - Ağız kokusu } \\
\text { - Stomatit } \\
\text { - Kilo kaybı } \\
\text { - Kanama } \\
\text { - }\end{array}$ & $\begin{array}{l}\text { 1100- Ağız sağlığı } \\
\text { 1101- Doku } \\
\text { bütünlüğ̈̈: Deri ve } \\
\text { mükoz membranlar } \\
\\
\text { Ağız Sağlığı İçin Bazı } \\
\text { Göstergeler } \\
\text { (1-5 arası puanlanır) } \\
\text { - Oral mukoza ve } \\
\text { dilin nemliliği } \\
\text { - Müköz } \\
\text { membranların rengi } \\
\text { - Oral mukoza } \\
\text { bütünlüğü } \\
\text { - Oral mukoza } \\
\text { lezyonları } \\
\text { - Dilin bütünlüğü } \\
\text { - Dişetlerinin } \\
\text { bütünlüğ̈ } \\
\text { - Kanama } \\
\text { - Ağız kokusu }\end{array}$ & 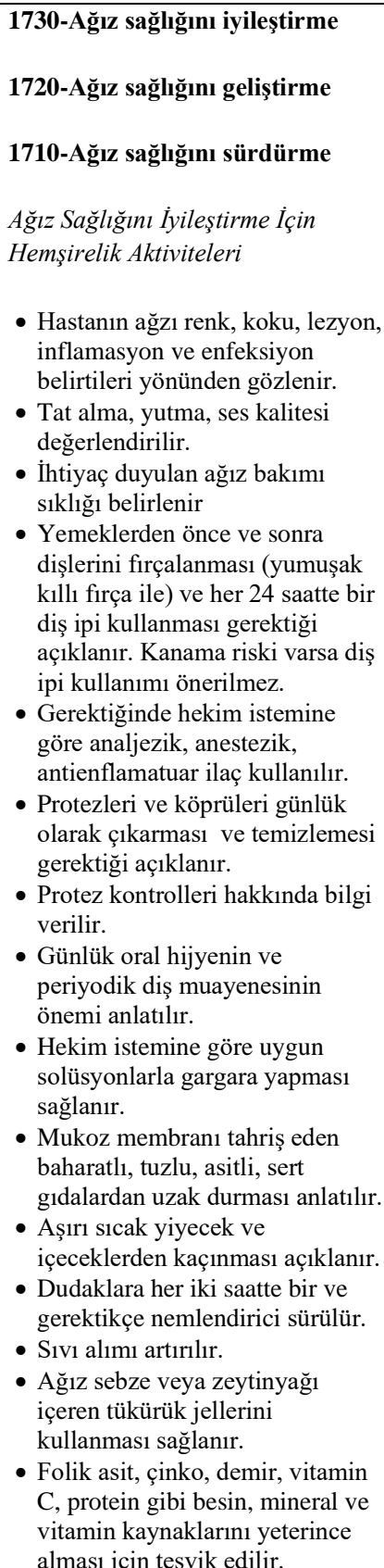 \\
\hline
\end{tabular}


Tablo 1 (Devam). Ağız ve diş sağlığı sorunu olan hastaların hemşirelik bakımında ele alınması gereken hemşirelik tanıları (pes formatında), hemşirelik sonuçları ve hemşirelik girişimleri.

\begin{tabular}{|c|c|c|c|c|}
\hline $\begin{array}{l}\text { Hemşirelik } \\
\text { Tanısı }\end{array}$ & $\begin{array}{l}\text { Etiyolojik } \\
\text { faktörler }\end{array}$ & $\begin{array}{l}\text { Tanımlayıcı } \\
\text { özellikler }\end{array}$ & NOC sonuçları & NIC girişimleri \\
\hline $\begin{array}{l}\text { Lateks alerji } \\
\text { riski }\end{array}$ & $\begin{array}{l}\text { Risk Faktörleri } \\
\text { - Tropikal meyve } \\
\text { alerjisi } \\
\text { - Çiçek alerjisi } \\
\text { - Astım öyküsü } \\
\text { - Hergün ya da sık } \\
\text { sık latekse maruz } \\
\text { kalma } \\
\text { (Üriner kateterler, } \\
\text { lateks eldivenler, } \\
\text { amalgam } \\
\text { taşıyıcıları, matrix } \\
\text { bantları ve } \\
\text { matrixler, anestezik } \\
\text { karpüller, } \\
\text { enjektörler, } \\
\text { damlalıklar, } \\
\text { endodontik dolgu } \\
\text { materyalleri, ölçü } \\
\text { materyalleri,maskel } \\
\text { er/yüz koruyucular, } \\
\text { ortodontik rubber } \\
\text { bantlar ve elastikler, } \\
\text { 1sırma plağı, polisaj } \\
\text { diskleri, suction } \\
\text { başlığı vb.) }\end{array}$ & 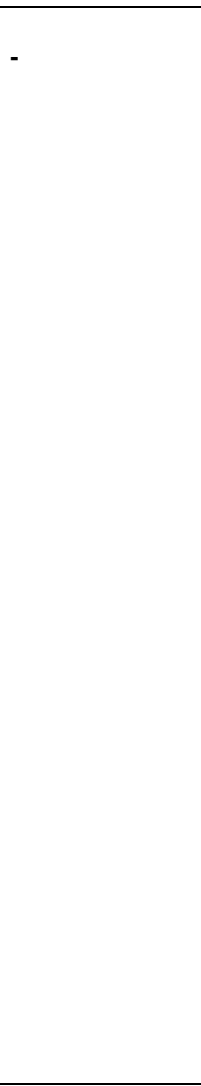 & $\begin{array}{l}\text { 0706-Alerjik tepki } \\
\text { 0802-Vital bulgular } \\
\text { 1902-Risk kontrolü } \\
\text { Alerjik tepki Iç̧in } \\
\text { Bazı Göstergeler } \\
\text { (1-5 arası } \\
\text { puanlanır) } \\
\text { - } \quad \text { Larinks ödemi } \\
\text { - İstirahatte dispne } \\
\text { - Taşikardi } \\
\text { - } \text { Düşük kan } \\
\text { basıncı } \\
\text { - } \text { Fasial ödem } \\
\text { - Kulantı } \\
\text { - Kusma } \\
\text { - Anarın ağrısı } \\
\text { Anaktik şok }\end{array}$ & $\begin{array}{l}\text { 6610-Risk tanılama } \\
\text { 6140-Kod yönetimi } \\
\text { 6410-Alerji yönetimi } \\
\text { 6680-Vital bulguları izleme } \\
\text { Risk Tanılama İçin Hemşirelik Aktiviteleri } \\
\text { - Geçmiş sağlık öyküsünü, var olan/önceki tıbbi ve } \\
\text { hemşirelik tanıları ile tedavilerini kanıtlayan } \\
\text { belgeler gözden geçirilir. } \\
\text { - Rutin risk değerlendirme ölçütlerinden elde } \\
\text { edilen veriler gözden geçirilir. } \\
\text { - Risk faktörlerini azaltmaya yardımcı olacak } \\
\text { kurumsal kaynaklar belirlenir. Örneğin lateks } \\
\text { içermeyen malzemelerin tercih edilmesi gibi } \\
\text { - Biyolojik, çevresel ve davranışsal riskler ve } \\
\text { bunlar arasındaki ilişkiler belirlenir. } \\
\text { - Tipik baş etme stratejileri belirlenir. Örneğin } \\
\text { lateksle teması nasıl önlüyor? } \\
\text { Temel yaşam gereksinimlerinin durumu } \\
\text { belirlenir. } \\
\text { Tıbbi ve hemşirelik tedavilerine uyumu } \\
\text { belirlenir. } \\
\text { - Risk faktörleri hakkında bilgilendirilir ve riski } \\
\text { azaltmak için plan yapılır. } \\
\text { Riskin azaltılmasına yönelik öncelikli alanlardaki } \\
\text { faydalı kriterler (örn; farkındalık ve motivasyon } \\
\text { düzeyi, etkililik, maliyet, uygulanabilirlik, } \\
\text { tercihler, eşitlik, etiketlenme/damgalanma ve } \\
\text { riskler belirlenmeden kalırsa sonuçların ciddiyeti) } \\
\text { göz önünde bulundurulur. } \\
\text { Bireyle ya da grupla işbirliği içinde riskin } \\
\text { azaltılmasına yönelik aktiviteler planlanır. } \\
\text { Risk azaltma stratejileri ve aktivitelerinin uzun } \\
\text { dönem izlemine yönelik plan yapılır }\end{array}$ \\
\hline $\begin{array}{l}\text { Şok riski } \\
\text { Vücut doku ve } \\
\text { organlarına giden } \\
\text { kan akımının } \\
\text { yetersizleşerek } \\
\text { dokulardaki } \\
\text { oksijenlenmenin } \\
\text { azalması ve bunun } \\
\text { sonucunda yaşamı } \\
\text { tehlikeye } \\
\text { sokabilecek } \\
\text { şekilde bozulma } \\
\text { riski taşıyan bir } \\
\text { bireydeki } \\
\text { durumdur. }\end{array}$ & $\begin{array}{l}\text { Risk Faktörleri } \\
\text { - Alerjik reaksiyon } \\
\text { - Kanama }\end{array}$ & & $\begin{array}{l}\text { 0802-Vital bulgular } \\
\text { 0706-Alerjik tepki } \\
\text { 1902- Risk } \\
\text { kontrolü } \\
\text { 0413-Ciddi kan } \\
\text { kaybı } \\
\\
\text { Vital Bulgular İçin } \\
\text { Bazı Göstergeler } \\
\text { (1-5 arası } \\
\text { puanlanır) } \\
\text { - Sistolik kan } \\
\text { basıncı } \\
\text { - Diyastolik } \\
\text { kanbasıncı } \\
\text { - Nabız hızı } \\
\text { - Solunum hızı } \\
\text { - Vücut sıcaklığı }\end{array}$ & $\begin{array}{l}\text { 4260-Şokun önlenmesi } \\
\text { 4250- Şok yönetimi } \\
\text { 6410-Alerji yönetimi } \\
\text { 4010-Kanama önlemleri } \\
\text { 6680-Vital bulguları izleme } \\
\text { Şokun Önlenmesi İçin Hemşirelik Aktiviteleri } \\
\text { - Hipotansiyon, yetersiz organ perfüzyonu gibi } \\
\text { şoku hızlandıran durumlar belirlenir } \\
\text { - Kloaritromisin, eritromisin, kalsiyum kanal } \\
\text { blokerleri gibi ilaçların ciddi hipotansiyona ve } \\
\text { şoka yol açabileceği bilinmelidir. } \\
\text { - Hastada rinit, hırıltılı solunum, dispne, kaşıntı, } \\
\text { ürtiker, diyare, anksiyete, huzursuzluk gibi alerjik } \\
\text { reaksiyonların erken belirtileri izlenir. } \\
\text { - Sıvı kaybının olası nedenleri izlenir. } \\
\text { - Dolaşım durumu (kan basıncı, cilt rengi, cilt ısısı, } \\
\text { kalp sesleri, kalp hızı ve ritmi, periferal nabızların } \\
\text { alınması ve kalitesi, kapiller dolum) izlenir. } \\
\text { - Endişe, ajitasyon, siyanoz gibi yetersiz } \\
\text { oksijenleme belirtileri ve pulseoksimetre değeri } \\
\text { ile oksijenizasyon durumu izlenir. } \\
\text { - Mukoz membranların durumu, peteşi ve morarma } \\
\text { izlenir. } \\
\text { - Oksijen tedavisi başlanır. } \\
\text { - Uygun pozisyon verilir: bacaklar eleve ya da } \\
\text { sırtüstü (vazojenik şokta), baş ve omuzlar eleve } \\
\text { - İrtüstü pozisyon (kardiyojenik şokta). } \\
\text { - İdrar miktarı izlenir } \\
\text { - Heku tetikleyen faktörlere karşı hasta ve ailesi } \\
\text { bilgilendirilir }\end{array}$ \\
\hline
\end{tabular}




\section{SONUÇ}

Bakım sürecinde sistematik ve bütüncül bir yaklaşıma rehber olması için yazılan bu makalede ağız ve diş sağ $l_{1} \breve{g}_{1}$ hizmetlerinden yararlanan hastalara uygun olacağ düşünülen, NANDA 2018-2020 hemşirelik tanıları listesinde yer alan 18 hemşirelik tanısına yer verilmiştir. Hemşirelik tanıları PES (Problem-EtiyolojiSemptom/Tanımlayıcı Özellik) formatına göre ele alınmıştır. Hasta durumunun değerlendirilmesinde yararlanılan 24 NOC ölçeği ve ölçeklere uygun NOC göstergeleri, 37 NIC girişimi ve bu girişimlere uygun hemşirelik aktiviteleri tablo olarak sunulmuştur.

\section{Çıkar çatışması beyanı}

Araştırmada herhangi bir çıkar çatışması yoktur.

\section{Yazar katkıları}

Yazının ortaya çıkması ve sürdürülmesine katkıda

bulunma: BAR, KE

Plan, tasarım: BAR, KE

Literatürün gözden geçirilmesi: BAR, KE

Kaleme alma ve düzeltmeler: BAR, KE

Kontrol etme ve gözden geçirme:BAR, KE

\section{Kurumsal ve finansal destek beyanı}

Kurumsal ve finansal destek yoktur.

\section{KAYNAKLAR}

Ackley, B.J., Ladwig, G.B., Makic, M.B.F (2019). Hemşirelik tanıları el kitabı. (N.Gürhan, Ü. Görgülü-Polat, B.ErenFidanc1, Çev.) Ankara: Ankara Nobel Kitabevleri

Akar, Ç. (2014). Türkiye'de ăgız-diş să̆lı̆̆ hizmetlerinin strateji değerlendirmesi. Ankara: Türk Diş Hekimleri Birliği Yayınları.

Birol, L. (2011). Hemşirelik süreci: Hemşirelik bakımında sistematik yaklaşım. İzmir: Etki Yayınları.

Butcher, H.K., Bulechek, G.M., Dochterman, J.M., \& Wagner, C.M. (Ed.). (2018). Nursing interventions classification (NIC) (7th ed.). St. Louis, MO: Elsevier.

Çolak, H., Dülgergil, T.Ç., \& Serdaroğlu, İ. (2010). Ağız ve diş hastalıklarının medikal, psikososyal ve ekonomik etkilerinin değerlendirilmesi. Sağllkta Performans ve Kalite Dergisi, 2(2), 63-89.

Carpenito-Moyet, L.J. (2012). Hemșirelik tanıları el kitabı.(F. Erdemir, Çev.) İstanbul: Nobel Tip Kitapevi

Herdman, H., \& Kamitsuru, S. (2018). Nursing diagnoses definitions and classification 2018-2020 (11 th ed.) New York: Wiley Blackwell.

Johnson, M., Bulechek, G.M, Dochterman, J.M.M., Maas, M.L., Moorhead, S., Swanson, E.,.... \& Butcher, H.K. (2012). NOC and NIC linkages to NANDA-I and clinical conditions. Supporting clinical reasoning and quality care. E-Book (3th ed.). United States of America: Mosby.

Kılınç, G., \& Günay, T. (2010). Dokuz Eylül Üniversitesi Tıp Fakültesi son sınıf öğrencilerinin ağız diş sağlığı konusunda bilgi düzeyleri. Dokuz Eylül Üniversitesi Tip Fakültesi Dergisi, 24(3), 131-7.

Karamanoğlu, A.Y., \& Yavuz, M. (2015). Ağız sağlı̆̆ hemşirelik değerlendirmesinde kanıtlar ve uygulama önerileri. Ege Üniversitesi Hemşirelik Fakültesi Dergisi, 31(1), 131-143.

Kozier, B., Berman, A., Snyder, S., \& Erb, G. (2008). Fundamentals of nursing concepts, process and practice. New Jersey: Prentice Hall. Upper Saddle River.
Moorhead, S., Swanson, E., Johnson, M., \& Maas, M. L. (2018). Nursing outcomes classification (NOC): Measurement of health outcomes (6th ed.). St. Louis: MO: Elsevier.

Nanda Nursing Diagnosis List. (2020). Retrieved May 03. 2020 from http://www.nandanursingdiagnosislist.org/

Naito, M., Yuasa, H., Nomura, Y., Nakayama, T., Hamajima, N., \& Hanada, N. (2006). Oral health status and health related quality of life: A systematic review. Journal of Oral Science, 48(1),1-7. https://doi.org/10.2334/josnusd.48.1

Potter, P., \& Perry, A. (2009). Fundamentals of Nursing. USA: Mosby Company. St. Louis: Elsevier.

Park, H. (2014). Identifying core NANDA-I nursing diagnoses, NIC interventions, NOC outcomes, and NNN linkages for heart failure. International Journal of Nursing Knowledge, 25(1), 30-38. https://doi.org/10.1111/2047-3095.12010

Rabelo-Silva, E.R., Dantas Cavalcanti, A.C., Ramos Goulart Caldas, M.C., Lucena, AdF., Almeida, MdA., Linch, GFdC.,... \& Müller-Staub, M. (2017). Advanced nursing process quality: Comparing the International Classification for Nursing Practice (ICNP) with the NANDA-International (NANDA-I) and Nursing Interventions Classification (NIC). Journal of Clinical Nursing, 26(3-4) 379-387. https://doi.org/10.1111/jocn.13387

Royal College of Nursing- RCN. (2011). Essantial guide. promoting older people's oral health. Retrieved June 10, 2014 from. http:// renpublishing. com/userimages/ content editor/ promoting-older-peoples-oral-health.pdf.

Slade, G.D. (2002). Assesment of oral health-related quality of life. Inglehart, M.R, Bangramian, R.A.(Ed) Oral health realted quality of life (pp.29-46) Chicago: Quintessence Publishing Co Inc.

Sabuncu, N. (2008). Hemşirelik süreci. N. Sabuncu, (Ed), Hemşirelik bakımında ilke ve uygulamalar (ss. 137-141) Ankara: Alter Yayıncilık.

Tatar, M., Mollahaliloğlu, S., Şahin, B., Aydın, S., Maresso, A., \& Hernandez-Quevedo C. (2011). Turkey: Health system review. Health Systems in Transition, 13(6), 1186

Taylor, C., Lillis, C., Lemone, P., \& Lynn, P. (2008). Fundamentals of nursing the art and science of nursing care. New York: Philadelphia: Wolter Kluwer. Lippincot Williams\&Wilkins.

Tastan, S., Linch, G.C., Keenan, G.M., Stifter, J., McKinney, D., Fahey, L.,.... \& Wilkie, D.J. (2014). Evidence for the existing American Nurses Association recognized standardized nursing terminologies: A systematic review. International Journal of Nursing Studies, 51(8), 1160-1170. https://doi.org/10.1016/j.ijnurstu.2013.12.004

Törnvall, E., \& Jansson, I. (2017). Preliminary evidence for the usefulness of standardized nursing terminologies in different fields of application: A literature review. International Journal of Nursing Knowledge, 28(2), 109119. https://doi.org/10.1111/2047-3095.12123

Wilkinson, J.M., Barcus, L. (2018). Hemşirelik tanıları el kitabı. (S. Kapucu, İ. Akyar, F. Korkmaz, Çev.) Ankara: Pelikan Yayınevi. 